\title{
A systematic literature review of leptospirosis outbreaks worldwide, 1970-2012
}

\author{
Claudia Munoz-Zanzi, ${ }^{1}$ Emily Groene, ${ }^{1}$ Bozena M. Morawski, ${ }^{1}$ Kimberly Bonner, ${ }^{1}$ Federico Costa, ${ }^{2}$ \\ Eric Bertherat, ${ }^{3}$ and Maria Cristina Schneider ${ }^{4}$
}

Suggested citation Munoz-Zanzi C, Groene E, Morawski BM, Bonner K, Costa F, Bertherat E, et al. A systematic literature review of leptospirosis outbreaks worldwide, 1970-2012. Rev Panam Salud Publica. 2020;44:e78. https://doi.org/10.26633/RPSP.2020.78

ABSTRACT Objective. This review describes the geographic and temporal distribution of, detection methods for, and other epidemiological features of published leptospirosis outbreaks, with the aim of informing efforts to standardize outbreak-reporting practices.

Methods. We conducted a systematic review of leptospirosis outbreaks reported in the scientific literature and ProMED during 1970-2012. Predefined criteria were used to identify and classify outbreaks and a standard form was used to extract information.

Results. During 1970-2012, we identified 318 outbreaks (average: 7 outbreaks/year; range: 1-19). Most outbreaks were reported in the Latin America and the Caribbean region (36\%), followed by Southern Asia (13\%), and North America (11\%). Most outbreaks were located in tropical and subtropical ecoregions (55\%). Quality classification showed that there was clear description of laboratory-confirmed cases in $40 \%$ of outbreaks. Among those, the average outbreak size was 82 cases overall (range: 2-2 259) but reached 253 cases in tropical/subtropical ecoregions. Common risk factors included outdoor work activities (25\%), exposure to floodwaters (23\%), and recreational exposure to water (22\%). Epidemiologic investigation was conducted in $80 \%$ of outbreaks, mainly as case interviews. Case fatality was $5 \%$ overall (range: $0 \%-60 \%$ ).

Conclusions. Outbreak reporting increased over the study period with outbreaks covering tropical and non-tropical regions. Outbreaks varied by size, setting, and risk factors; however, data reviewed often had limited information regarding diagnosis and epidemiology. Guidelines are recommended to develop standardized procedures for diagnostic and epidemiological investigations during an outbreak and for reporting.

Keywords Leptospirosis; Leptospira; disease outbreaks; zoonoses; public health surveillance.

Leptospirosis is a zoonotic infection caused by the pathogenic species of the spirochete bacteria Leptospira. The infection will remain subclinical in the majority of infected people. Infected people who are symptomatic often have non-specific symptoms, like those found in dengue, malaria, and influenza. However, leptospirosis can also be deadly in up to $10 \%$ of patients (1). Human infection is mostly caused through contact with water or soil contaminated with urine from animals shedding Leptospira, including rats, livestock, dogs, and wildlife. Leptospira is distributed worldwide, but is especially prevalent in tropical climates due to favorable environmental conditions for pathogen survival. Modeling of the global burden of leptospirosis estimated an annual morbidity of 14.8 cases per 100000 population, with 1.03 million cases and 58900 deaths due to leptospirosis each year (1). Prevalence is often endemic at varying levels, from very low levels in temperate regions (2) to hyperendemic with strong seasonality in tropical regions (3).

The visibility of leptospirosis as an important public health problem increases when there are recognized outbreaks, which are often linked to floods, natural disasters $(4,5)$, and

\footnotetext{
University of Minnesota, Minneapolis MN, United States of America.

$\triangle$ Claudia Munoz-Zanzi, munozzan@umn.edu

2 Universidade Federal da Bahia, Salvador BA, Brazil.
}

\footnotetext{
3 World Health Organization, Geneva, Switzerland

4 Pan American Health Organization, Washington DC, United States of America.
} 
water-sports events $(6,7)$. However, there are many gaps in the understanding of risk factors for outbreaks, determinants of their magnitude, and options for early detection and prediction (8). Despite leptospirosis being reportable in many countries (9), limitations of laboratory diagnosis and reporting affect systematic case data collection, outbreak detection, and complete characterization of outbreaks. The objective of this study was to characterize the frequency, epidemiology, and clinical features of leptospirosis outbreaks, as well as reporting practices, by conducting a systematic review of the scientific literature and ProMED, an Internet-based outbreak reporting system.

\section{MATERIALS AND METHODS}

Potential articles for the systematic review were identified by searching 38 electronic database sources (list available from corresponding author upon request) for articles published and indexed from 1 January 1970 to 31 December 2012, which contained the terms "Leptospira," "leptospirosis," "Weil disease," or "Weil's disease," while excluding "Leptospirillum." Search term strings were customized to each electronic database's individual subject headings and query structure. For regional and non-English databases, relevant translations of leptospirosis were included in searches; e.g., "leptospirose" for African Index Medicus. Reports were stored and organized using RefWorks ${ }^{\circledR}$ bibliographic software to initially detect duplicates. Reports from gray material were collected from ProMED and entered manually.

We reviewed article titles and abstracts to identify and exclude: i) reports with no data; i.e., literature reviews, letters, and other reports on human leptospirosis that did not contain data or that discussed leptospirosis generally; ii) reports with data collected before 1970 and after 2012; and, iii) reports with data unrelated to human cases; i.e., articles related to wildlife, laboratory, or animal reservoirs. Articles were classified as describing human leptospirosis outbreaks if they described an event or events meeting the following criteria: i) event classified by the author or reporting entity as an "outbreak," or "epidemic," or "elevated" number of human leptospirosis cases; or, ii) event included at least two suspected cases that were geographically and temporally related. Final articles were assessed for leptospirosis outbreak accuracy based on the following reporting quality criteria: i) description of laboratory diagnosis of cases using the World Health Organization (WHO) Leptospirosis Disease Burden study definitions (1); ii) outbreak case ascertainment method (community or hospital/provider-based); and, iii) description of defined outbreak time. Based on these criteria, outbreaks were classified into Option 1 (those with $\geq 1$ confirmed or probable case without any other criteria), Option 2 (those with $\geq 1$ confirmed case without any other criteria), Option 3 (those with $\geq 1$ confirmed case and defined time period), and Option 4 (those with $\geq 1$ confirmed case, defined time period, and active case ascertainment) (Table 1). We assessed outbreak classification quality control by reclassifying a $15 \%$ random sample of all reports. Inter-rater agreement was also assessed in a $10 \%$ random sample of outbreak reports. In the case of uncertain classification, CMZ made final inclusion decisions.

\section{Data analysis}

Part 1 of the analysis described all outbreaks (regardless of accuracy quality criteria) by location, year of occurrence, size, and setting. In addition to country and WHO region, location was classified by ecoregion based on the Terrestrial Ecoregions of the World (10). Ecoregions are defined as relatively large units of land or water containing a distinct assemblage of natural communities that share a large majority of species, dynamics, and environmental conditions. There are 867 terrestrial ecoregions, classified into 14 different biomes such as forests, grasslands, or deserts (10). Part 2 of the analysis characterized outbreaks meeting Option 2 criteria; i.e., reporting $\geq 1$ laboratory-confirmed case, by case demography, risk factors, and clinical manifestations.

\section{RESULTS}

\section{Overall description of all outbreaks $(N=318)$}

Search results. We reviewed a total of 19454 search results across 38 databases for leptospirosis outbreaks (Figure 1). The review yielded 318 leptospirosis outbreaks (270 from

TABLE 1. Assessment checklist to evaluate the quality of evidence for leptospirosis outbreak from a systematic literature review, 1970-2012

\begin{tabular}{|c|c|c|c|c|c|}
\hline Quality criteria & Leptospirosis outbreak definition & $\begin{array}{l}\text { Laboratory confirmation } \\
\text { with standard methods } \\
\text { and definitions }{ }^{a}\end{array}$ & $\begin{array}{c}\text { Case ascertainment whether } \\
\text { community or hospital/ } \\
\text { provider-based }\end{array}$ & Time period & Number of outbreaks \\
\hline All & $\begin{array}{l}\text { By author or at least two } \\
\text { epidemiologically related cases }\end{array}$ & $\ldots$ & $\ldots$ & $\ldots$ & 318 \\
\hline Option 1 & $\begin{array}{l}\text { By author or at least two } \\
\text { epidemiologically related cases }\end{array}$ & $\begin{array}{l}\text { Outbreak with at least one } \\
\text { confirmed case or with } \\
\text { probable cases only }\end{array}$ & $\cdots$ & $\ldots$ & 188 \\
\hline Option 2 & $\begin{array}{l}\text { By author or at least two } \\
\text { epidemiologically related cases }\end{array}$ & $\begin{array}{l}\text { Outbreak with at least one } \\
\text { confirmed case }\end{array}$ & $\cdots$ & $\ldots$ & 127 \\
\hline Option 3 & $\begin{array}{l}\text { By author or at least two } \\
\text { epidemiologically related cases }\end{array}$ & $\begin{array}{l}\text { Outbreak with at least one } \\
\text { confirmed case }\end{array}$ & $\cdots$ & $\begin{array}{l}\text { Defined duration } \\
\text { reported }\end{array}$ & 86 \\
\hline Option 4 & $\begin{array}{l}\text { By author or at least two } \\
\text { epidemiologically related cases }\end{array}$ & $\begin{array}{l}\text { Outbreak with at least one } \\
\text { confirmed case }\end{array}$ & $\begin{array}{l}\text { Active ascertainment of } \\
\text { cases whether community } \\
\text { or hospital/provider-based }\end{array}$ & $\begin{array}{l}\text { Defined duration } \\
\text { reported }\end{array}$ & 54 \\
\hline
\end{tabular}


FIGURE 1. Flow chart of a systematic literature review of leptospirosis outbreaks reported in scientific literature from 1970 to 2012

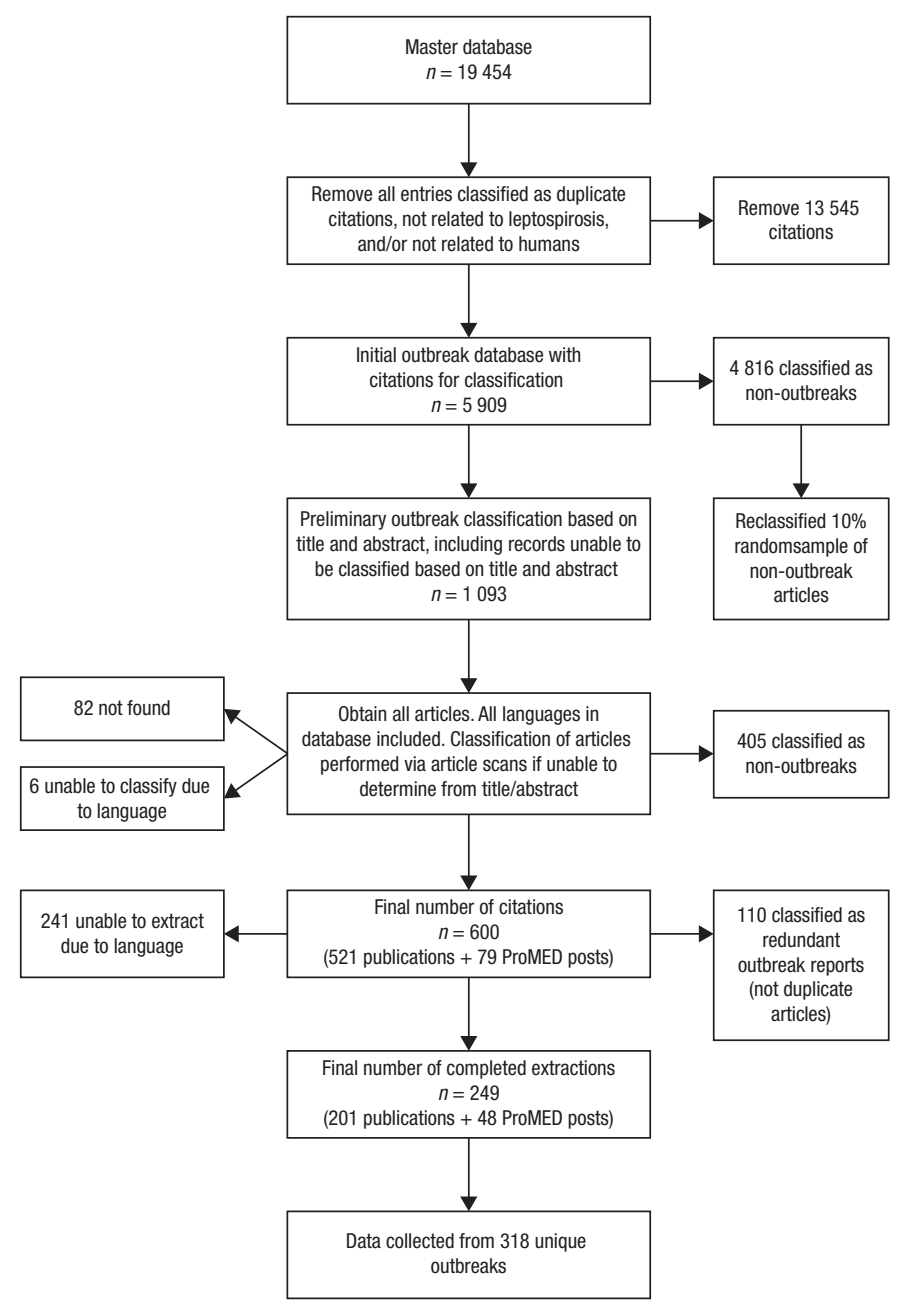

Source: Prepared by authors from study-collected data

scientific literature and 48 from ProMED) from 64 different countries. Seventy percent $(n=222)$ were in English and the rest were translated from Spanish $(n=62)$, Portuguese $(n=14)$, French $(n=7)$, Georgian $(n=6)$, Japanese $(n=3)$, Italian $(n=2)$, Russian $(n=1)$, and Bosnian $(n=1)$.

Regional distribution. The regions of the world reporting the most outbreaks were Latin America and the Caribbean with $35.8 \%$ (114/318), followed by Southern Asia with $12.9 \%$ (41/318), and North America with 10.7\% (34/318) (Figure 2). Among outbreaks occurring in the Latin America and the Caribbean region, $45.6 \%(52 / 114)$ were located in the Caribbean (mostly Cuba with 42 outbreaks) and 45.6\% (52/114) in South America (mostly Brazil with 28 outbreaks). At the country level, the highest numbers of leptospirosis outbreaks were reported in Cuba (13.2\%; 42/318), followed by India $(11.9 \% ; 38 / 318)$, and the United States of America (10.4\%; 33/318).

Outbreaks by ecoregion. The largest proportions of the outbreaks were located in the tropical and subtropical moist broadleaf forest ecoregion $(32.1 \% ; 102 / 318)$ and the tropical and subtropical dry broadleaf forest ecoregion $(22.6 \% ; 72 / 318)$.
This was followed by outbreaks in the temperate broadleaf and mixed forest ecoregion $(21.7 \% ; 69 / 318)$ (Figure 2). Many outbreaks in tropical and subtropical forest were in Eastern, Southeast, and Southern Asia, with most of them in coastal cities and islands. All the outbreaks reported in Middle and Western Africa $(n=24)$ were in the tropical/subtropical moist broadleaf forest. Outbreaks occurring in North, Central, and South America occurred in diverse ecoregions, e.g., tropical, subtropical, temperate, and Mediterranean ecoregions; outbreaks occurring in Central America and the Caribbean tended to be near coastal cities and islands. Among outbreaks occurring in Europe, the most common ecoregion was temperate broadleaf and mixed forest.

Temporal distribution. During 1970-2012, there was an average of seven outbreaks each year (range: 1-19) (Figure 3). Reporting increased after 1993 and peaked during 1997-1999 $(n=44)$. Twelve outbreaks were extracted from reports published in the study period that did not include information about when the outbreak occurred.

Outbreak setting. Outbreaks were reported to have occurred in urban, rural, and mixed urban/rural settings in 16\% (52/318), $15 \%(47 / 318)$, and $9 \%(27 / 318)$ of reports, respectively. In $24 \%$ $(76 / 318)$ of outbreaks, information provided did not allow for setting classification. The lowest proportion of urban outbreaks was reported during 1979-1984 (0\%), increasing to 47\% during 2000-2002. Eighty-three of the 318 (26\%) outbreaks occurred in an occupational setting, of which $66 \%(55 / 83), 7 \%(6 / 83)$, and $27 \%(22 / 83)$ were in a rural, urban, or undetermined occupational settings, respectively. Occupational setting-associated outbreaks were most common during 1985-1987 (47.6\%; 10/21), 1988-1990 (69.2\%; 9/13), and 1991-1993 (53.3\%; 8/15), with a decreasing trend after 1993. The overall number of outbreaks in a recreational setting was small $(10.4 \% ; 33 / 318)$; however, it represented $23.8 \%(5 / 21)$ of outbreaks in $1985-1987$ and $17.6 \%$ $(6 / 34)$ of outbreaks in 2009-2012.

\section{Laboratory-confirmed outbreaks $(N=127)$}

At least one laboratory-confirmed leptospirosis case was reported clearly in 39.9\% (127/318) of all outbreaks, in addition to probable and/or suspect cases. Sixty-one outbreaks reported probable cases only, which were diagnosed serologically using ELISA and/or microagglutination test (MAT). The proportion of outbreaks with laboratory-confirmed cases was greatest in the earlier years of this review, with 60\% (9/15) in 1970-1972 and $73.3 \%(11 / 15)$ in 1973-1975 and a decreasing trend over time. The proportion in the later years, 2009-2012, was $23.5 \%$ $(8 / 34)$. Eighty-six outbreaks had $\geq 1$ confirmed leptospirosis case and stated a defined time for the outbreak duration (Option 3); active case ascertainment was used in 54 of those outbreaks (Option 4). Only the 127 outbreaks that reported $\geq 1$ laboratoryconfirmed case (Option 2) were used for the purpose of this further epidemiological and clinical characterization (Table 1).

Outbreak epidemiological characteristics. Overall average outbreak size was 82 cases (range: 2-2 259). The ecoregion with the largest average outbreak size was the tropical/subtropical dry broadleaf forest ecoregion (253 cases, $n=17$ ) followed by moist broadleaf forest ( 77 cases, $n=46)$, and temperate broadleaf forest ( 14 cases, $n=35)$. Extraction of risk factor information showed that $25 \%(32 / 127)$ of outbreaks were related to work activities such as farming and agriculture, as well as other 
FIGURE 2. Global distribution of human leptospirosis outbreaks reported in the literature by ecoregion obtained from a systematic literature review from 1970 to 2012

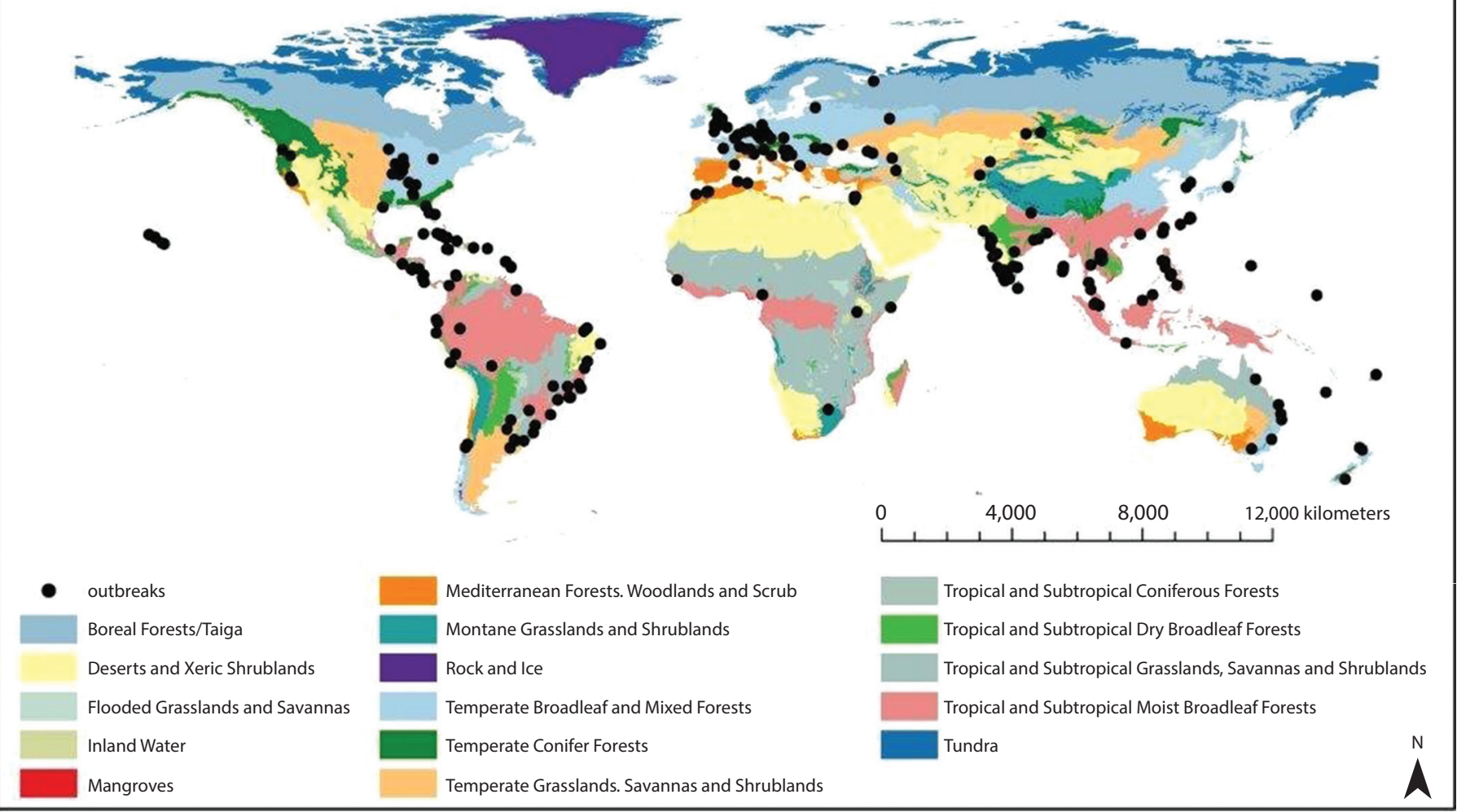

Source: Prepared by authors from study-collected data.

outdoor jobs that exposed people to rodents and contaminated environment (e.g., landscaping, sewer management). Exposure to floodwaters due to increased rainfall, monsoon, or natural disasters (e.g., typhoons) was identified in $23 \%$ of outbreaks $(29 / 127)$. Twenty-two percent $(28 / 127)$ of the outbreaks were linked to exposure to recreational swimming, water sports, or domestic use, e.g., bathing. A few outbreaks (4\%; 5/127) were linked to Leptospira exposure from dogs. Almost all outbreaks linked to swimming $(96 \% ; 27 / 28)$ and dog exposure $(80 \% ; 4 / 5)$ were described as point source. Twenty-three outbreaks (18\%) did not have enough information to determine outbreak setting.

Outbreak investigation. Outbreak investigation was carried out in $80 \%(101 / 127)$ of outbreaks. A formal outbreak investigation using a case-control approach to identify potential exposure sources was used in $26 \%$ of outbreaks (26/101). In a large majority (73\%; 4/101) of outbreaks, information on exposure was based on case interviews. Further investigation involving reservoir laboratory testing was carried out in 32\% (32/101) of outbreaks. In three instances, the human outbreak investigation was initiated subsequent to an animal leptospirosis outbreak. Among 92 outbreaks with available data, most common MAT titers were to serogroup Icterohaemorrhagiae occurring in outbreaks with swimming/water exposure, occupational, and flooding as risk factors. Titers to serogroup Sejroe were the second most common and present in occupational-related outbreaks. Further etiologic investigation $(n=38)$ through isolation found $L$. interrogans as the most common species and Icterohaemorrhagiae as the most common serovar. Reports from $8 \%$ of outbreaks $(10 / 127)$ described an intervention that was implemented as a result of the investigation, including measures to stop exposure (i.e., shutting down a fountain, pool closure, use of protective clothing, euthanasia of infected dog), use of chemoprophylaxis, use of vaccination, and education programs.

Demographic and clinical presentation. Of the 127 outbreaks with $\geq 1$ laboratory-confirmed case, 28\% (36/127) included adults only, $29 \%(37 / 127)$ included adults and children, $10 \%$ $(13 / 127)$ involved children only, and 32\% (41/127) did not provide age information. Based on 33 outbreaks with reliable sex distribution data, the average proportion of male cases was $77 \%$ (range: 40\%-100\%). Eighty-one percent (103/127) of outbreaks included clinical information about the patients (Table 2). Fever was reported in almost all outbreaks, and jaundice and renal failure were common complications. More adults-only outbreaks reported renal symptoms, anorexia, and altered mental state compared to outbreaks involving children. Conversely, pulmonary symptoms, meningitis, hepatitis, pancreatitis, ocular symptoms, and myalgia were more common among childrenonly outbreaks. Case fatality (number of deaths/number of confirmed leptospirosis cases) was calculated for 83 outbreaks reporting detailed case counts and vital status, resulting in 5\% (range: $0 \%-60 \%$ ) overall fatality, $1 \%$ (range: $0 \%-6 \%$ ) for 10 children-only outbreaks, $4 \%$ (range: $0 \%-60 \%$ ) for 34 adults-only outbreaks, $7 \%$ (range: $0 \%-35 \%$ ) for 24 generalized outbreaks, and $7 \%$ (range: $0 \%-51 \%$ ) for 15 outbreaks of undetermined age. 
FIGURE 3. Number of human leptospirosis outbreaks by setting obtained from a systematic review of literature between 1970 and $2012(n=306)^{\mathrm{a}}$

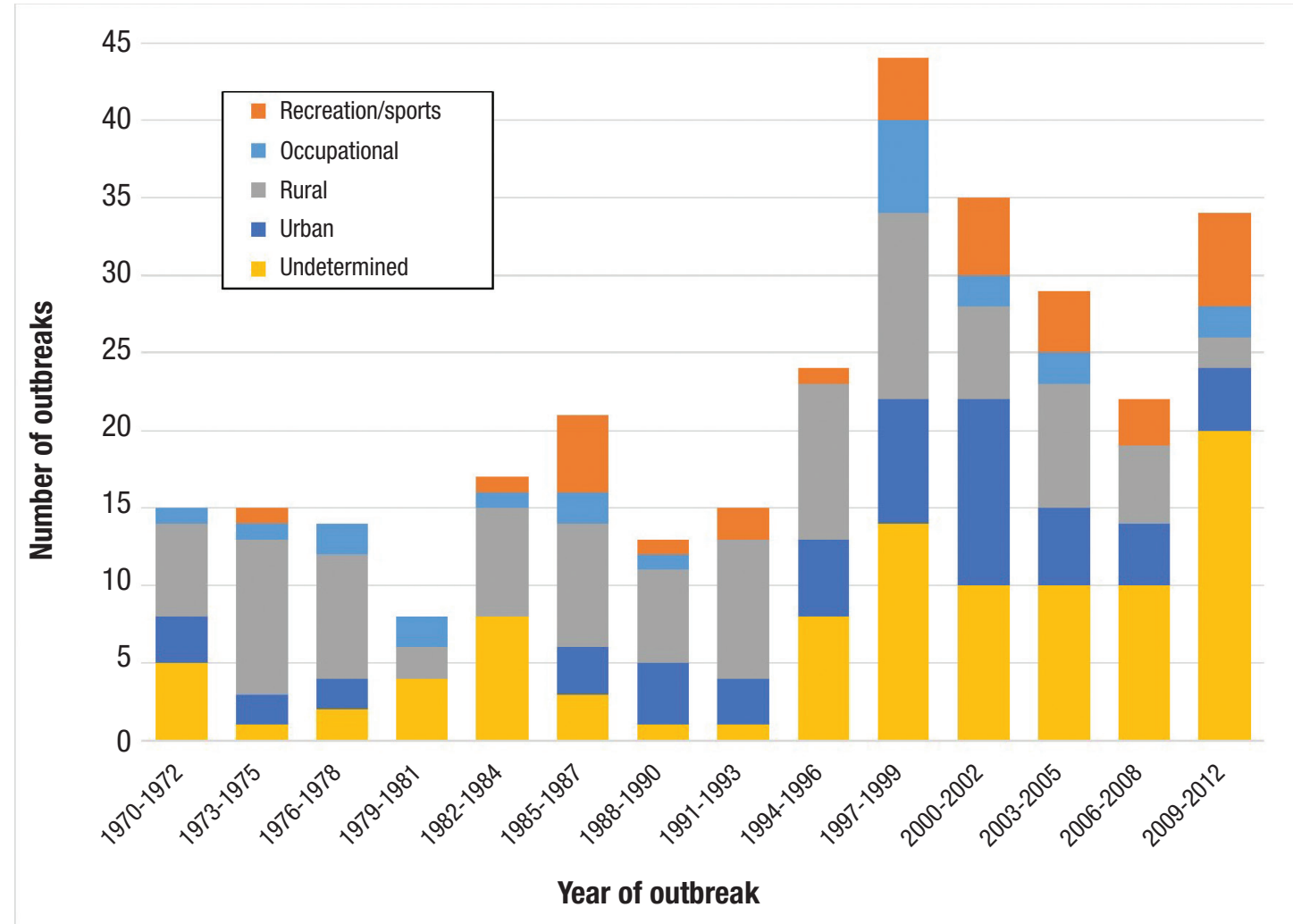

a 12 additional outbreaks were reported in the reviewed time period but did not include a specific year. Source: Prepared by authors from study-collected data.

TABLE 2. Number and proportion of leptospirosis outbreaks obtained from a systematic literature review from 1970 to 2012 reporting specific clinical manifestations

\begin{tabular}{|c|c|c|c|c|c|}
\hline \multirow[b]{2}{*}{$\begin{array}{l}\text { Clinical presentation } \\
\text { (number of outbreaks) }\end{array}$} & \multicolumn{4}{|c|}{ Outbreak age distribution ${ }^{\mathrm{a}}$} & \multirow[b]{2}{*}{$\begin{array}{c}\text { Total } \\
(n=103)^{4}\end{array}$} \\
\hline & $\begin{array}{l}\text { Children only } \\
\qquad(n=12)\end{array}$ & $\begin{array}{l}\text { Adults only } \\
\qquad(n=35)\end{array}$ & $\begin{array}{l}\text { Both } \\
(n=32)\end{array}$ & $\begin{array}{l}\text { Undetermined } \\
\qquad(n=24)\end{array}$ & \\
\hline Fever & $12(100 \%)$ & $31(89 \%)$ & $32(100 \%)$ & $20(83 \%)$ & $95(92 \%)$ \\
\hline Renal injury & $3(25 \%)$ & $17(49 \%)$ & $18(56 \%)$ & $8(33 \%)$ & $46(45 \%)$ \\
\hline Pulmonary injury & $3(25 \%)$ & $3(9 \%)$ & $11(34 \%)$ & $9(38 \%)$ & $26(25 \%)$ \\
\hline Meningitis, neurological & $5(42 \%)$ & $7(20 \%)$ & $8(25 \%)$ & $5(21 \%)$ & $25(24 \%)$ \\
\hline Uveitis, other eye symptoms & $3(25 \%)$ & $3(9 \%)$ & $3(9 \%)$ & $2(8 \%)$ & $11(11 \%)$ \\
\hline Anorexia, weight loss & $\ldots$ & $7(20 \%)$ & $\ldots$ & $2(8 \%)$ & $9(9 \%)$ \\
\hline Altered mental state & $\ldots$ & $2(6 \%)$ & $4(13 \%)$ & $\ldots$ & $6(6 \%)$ \\
\hline Hepatitis, pancreatitis & $2(17 \%)$ & $\ldots$ & $\ldots$ & $2(8 \%)$ & $4(4 \%)$ \\
\hline Myalgia, other pain & $1(8 \%)$ & $1(3 \%)$ & $1(3 \%)$ & $1(4 \%)$ & $4(4 \%)$ \\
\hline
\end{tabular}

a For a given age group, percentage is the proportion of outbreaks reporting occurrence of the specific clinical presentation ( $\geq 1$ patient).

$\mathrm{b} n=103$, total outbreaks with $\geq 1$ confirmed case and with clinical information in the report.
Source: Prepared by authors from study-collected data.

\section{DISCUSSION}

The number of reported leptospirosis outbreaks increased during the time period investigated in this review, with a particular increase after the mid-1990s. Results also revealed substantial differences in outbreak detection, diagnosis, methods of source identification, and response. Furthermore, this review revealed gaps in the quality and completeness 
TABLE 3. Recommendation for leptospirosis outbreak reporting based on findings from a systematic literature review, 1970-2012

\begin{tabular}{|c|c|c|}
\hline & Recommendations for reporting & Highlights from literature review \\
\hline Surveillance & $\begin{array}{l}\text { - Describe surveillance type (passive, active) } \\
\text { - Describe case ascertainment method (hospital-based, community-based) } \\
\text { - State outbreak definition including population, location, and duration }\end{array}$ & $\begin{array}{l}89 \% \text { had as outbreak definition "increase in number of cases" } \\
56 \% \text { had specific dates } \\
42 \% \text { did not state case finding process }\end{array}$ \\
\hline Diagnostics & $\begin{array}{l}\text { - State suspect, probable, and confirmed case definitions and case counts } \\
\text { - State laboratory diagnostic effort with respect to number of cases }\end{array}$ & $\begin{array}{l}52 \% \text { applied recognized case definitions } \\
40 \% \text { stated at least one laboratory-confirmed case } \\
\text { Increase in use of rapid tests without confirmation }\end{array}$ \\
\hline Outbreak characteristics & $\begin{array}{l}\text { - Describe setting (urban, rural) and source } \\
\text { - Describe epidemic curve and outbreak type (point source, continuous } \\
\text { common source) } \\
\text { - Describe case demographic features } \\
\text { - Describe number of deaths, fatality ratio } \\
\text { - Describe clinical features of cases and deaths }\end{array}$ & $\begin{array}{l}\text { Location often identified as city instead of population affected } \\
30 \% \text { with undetermined source, no or broad risk factors } \\
15 \% \text { with breakdown of cases by age, sex }\end{array}$ \\
\hline Outbreak response & $\begin{array}{l}\text { - Describe type of outbreak investigation } \\
\text { - Describe identification of causal agent } \\
\text { - Describe outbreak response and timeline }\end{array}$ & $\begin{array}{l}54 \% \text { with outbreak investigation } \\
10 \% \text { with outbreak response } \\
32 \% \text { reported causative agent }\end{array}$ \\
\hline
\end{tabular}

Source: Prepared by authors from study-collected data.

of reporting. Systematic detection and standardized reporting of outbreaks are necessary to understand determinants, mechanisms, and trends across different geographic regions. Leptospirosis continues to cause outbreaks resulting in excess illness, deaths, and health care costs (11-15). As with many other infectious diseases (16), attention to leptospirosis increases after recognized outbreaks, but dissipates after the emergency has subsided, resulting in the slow pace of outbreak research. Significant improvements in outbreak detection, investigation, and reporting quality are needed to better predict, prepare for, and reduce the health impact of leptospirosis outbreaks.

Table 3 contains a checklist of items involved in the process of outbreak detection, diagnosis, epidemiological investigation, and response with corresponding recommendations for developing reporting standards; it also highlights key barriers and limitations revealed in the data review. Although efforts to develop standards for diagnosis and clinical management of leptospirosis clinical cases are increasing (17-19), there are inadequate efforts to develop improved methods for outbreak research focused on leptospirosis. Furthermore, a lack of baseline surveillance information can lead to difficulties in accurately differentiating epidemic from background endemic disease transmission (20), resulting in unrecognized outbreaks, delayed responses, and missed opportunities to collect critical outbreak data.

Outbreaks were classified by criteria evaluating certainty of a leptospirosis outbreak (Table 1), based on description of laboratory-confirmed cases, that cases occurred within a defined time period, and that a reliable number of cases were obtained from active case ascertainment. These quality criteria were selected because leptospirosis can be misdiagnosed as other diseases (e.g., dengue, chikungunya, influenza, other acute viral or bacterial illnesses) $(18,21)$ and due to the need to recognize outbreaks as an increase in cases from baseline within a particular timeframe. In most outbreak reports, laboratory diagnosis for leptospirosis was attempted; however, only $40 \%$ clearly described identification of laboratory-confirmed cases (Table 1). Furthermore, 61 outbreaks reported only probable cases, which is consistent with an increase in the use of rapid tests based on detection of IgM antibodies. The need for access to specialized laboratories for MAT and/or PCR, the confirmatory tests, is a significant barrier to achieve confirmation and, in the face of an outbreak, antibiotic treatment without waiting for laboratory diagnostic results is recommended clinical practice (22). As the availability of various commercial rapid tests continues to increase (23), research is needed to identify their role in leptospirosis surveillance and accurate outbreak detection and response.

Temporal and geographic distribution of outbreaks showed an increase over time and widespread occurrence in various ecoregions globally (Figure 2) that are consistent with the known epidemiology of high incidence in tropical and subtropical ecoregions (1), although outbreaks occurred in non-tropical ecoregions as well. There was a noticeable gap in reports from countries in the African region, even in ecoregions generally suitable for leptospirosis transmission. Knowledge on leptospirosis in Africa is limited; however, more leptospirosis and febrile illness research is being done in various countries, including Tanzania $(24,25)$, the Central African Republic (26), and Burkina Faso (27). These studies have begun to reveal leptospirosis as a recurrent cause of febrile illness in the African region. More research will provide better information on risk areas and infection dynamics.

We observed an increase in the number of outbreak reports linked to floods, particularly during the later years included in the review (1994-2012). This association has long been recognized and believed to be the result of multiple factors. Increases in rainfall and floods of different magnitudes can alter the local ecology of leptospirosis as well as the animal reservoir and human population's conditions and behaviors. Heavy rain or excess water can facilitate dispersion of leptospires from the soil, where they can survive for long periods of time, to surface water (28). Lastly, displacement, interruption of rodent control activities, and reduced access to safe water can result in outbreaks, while disruptions of health care services can limit access to prompt care (20). Data review showed that while outbreaks after swimming or other recreational exposure to contaminated water were almost exclusively point source outbreaks, exposure sources in flood-related outbreaks are difficult to ascertain. The associations between rainfall, environmental exposure, and leptospirosis risk are being investigated with epidemiological 
(29-33) and laboratory methods $(34,35)$ to understand drivers and mechanisms. However, further research is needed in the area of outbreak prediction after heavy rains and related natural disasters, including the role of the environment as habitat of pathogenic Leptospira. Guidelines and recommendations exist for chemoprophylaxis for travel medicine or certain risk groups (i.e., military, rice farmers) expecting exposure to a potentially contaminated environment (36) but these need to be paired with improved surveillance information on local individual and outbreak risk factors to avoid unnecessary medication. Similarly, guidelines for chemoprophylaxis for longer-term occupational exposure to contaminated fields or floods need to be developed with an improved understanding of underlying outbreak risk (37).

Reliable and detailed data on sex and age distribution of cases were limited; nevertheless, outbreak demographics revealed a larger proportion of male than female cases, which is consistent with the known epidemiology of leptospirosis describing higher incidences in men due to higher exposure risk (1). Most outbreaks were in adult populations and there were a few children-only outbreaks (Table 2) with sources linked to special circumstances such as school or recreational activities. Limited clinical data in the outbreak reports suggested that fever was the most common manifestation overall and while more children-only outbreaks reported jaundice, pulmonary injury, and meningitis, more adults-only outbreaks reported renal injury. Comparative case studies have reported more jaundice and icteric forms of leptospirosis in adults than in children $(38,39)$. Similar to our findings, studies have reported more frequent acute renal injury (40) and higher fatality rate in adults than in children $(38,40)$. Pediatric leptospirosis is relatively less described in the literature and mild illness is common $(41,42)$. More research is needed to fully understand distinct clinical patterns that can help with early detection of outbreaks in children and diagnosis and treatment.

There are many elements influencing how these outbreaks were identified in our review, including existing surveillance systems to monitor trends and to identify outbreaks and laboratory capacity for diagnosis. Furthermore, this review was based on outbreaks reported in the scientific literature, which relies on investigators' interest and ability to publish. We included ProMED in an attempt to cover non-scientific reporting; however, information provided was generally minimal. Consequently, this review would underestimate the real impact of leptospirosis outbreaks. Authors' indication of a leptospirosis outbreak and its descriptive data may be subject to inaccuracy due to lack of baseline data, case misclassification, and different approaches to ascertain information. Additionally, the ability to assess temporal trends is limited due to changes in laboratory capacity and surveillance systems over time, and some of the increase in reported leptospirosis outbreaks may be attributed to expansion of laboratory access and/or changes in mandatory reporting regulations.

For many infectious diseases, current surveillance programs are not equipped with the necessary tools for early detection, prevention, and follow-up strategies (43). The need to strengthen surveillance systems is particularly pressing at the human-animal-environment interface, as spillover events, together with environmental drivers, can be a significant contributor to leptospirosis outbreaks. The coverage of leptospirosis surveillance is limited $(9,43)$ and further expansion is needed before leptospirosis outbreak patterns can be fully characterized. This is particularly important for areas expected to be suitable for leptospirosis transmission but currently silent. Among the reviewed sources, the completeness of reporting varied across the categories summarized in Table 3. Most reports indicated an outbreak definition, but other elements, particularly details in diagnostics and epidemiological description, were missing in a high number of outbreaks. Obtaining relevant surveillance information, in particular when facing large public health emergencies, is frequently challenging, but it is fundamental to understand outbreak impact, determinants, and contributing risk factors (20). Efforts should be made for a multisectoral and global effort to develop and use standardized outbreak data collection forms and user-friendly platforms for reporting.

\section{Conclusions}

Leptospirosis outbreaks had a widespread distribution and increased over the study period, in particular in tropical ecoregions. The impact can be significant due to the occurrence of large outbreaks and high fatality. However, outbreak reporting practices were variable and with often limited information regarding diagnosis and epidemiology. More research is needed to understand leptospirosis outbreak predictors and risk factors; however, lack of standardized diagnostic and epidemiological practices is a significant impediment. A concerted and global effort is needed to produce, and subsequently adopt, guidelines for detection, investigation, and reporting of leptospirosis outbreaks.

Author contributions. CMZ, MCS, EB, and FC contributed to developing the original concept. $\mathrm{CMZ}$ and $\mathrm{BMM}$ designed the review and collected the data. $\mathrm{CMZ}, \mathrm{EG}$, and $\mathrm{KB}$ performed data analysis. CMZ and MCS wrote the paper. All authors contributed to interpretation of results and reviewed and approved the final version.

Acknowledgments. We thank Christopher Campbell (University of Minnesota) for assistance with data extraction and data management and the following individuals for their contribution with data extraction of non-English reports: Brooke Higgins (University of Minnesota), Mageen Caines (University of Minnesota), Stefan Gherghelegiu (University of Minnesota), Tat'Yana Kenigsberg (University of Minnesota), Cynthia Yoon (University of Minnesota), Basant Motawi (WHO), Chisato Ito (Simon Fraser University), Malin Finkernagel (Paul-Ehrlich-Institut), Giorgia Sulis (Università degli Studi di Brescia), and Carmen Morawski (Boise State University). We acknowledge the Global Leptospirosis Environmental Action Network (GLEAN) as contributors to initial discussions on the scope of this review (CMZ, MCS, FC, and EB are GLEAN members).

Conflicts of interest. The authors declare no conflict of interest.

Disclaimer. Authors hold sole responsibility for the views expressed in the manuscript, which may not necessarily reflect the opinion or policy of the RPSP/PAJPH and/or the Pan American Health Organization. 


\section{REFERENCES}

1. Costa F, Hagan JE, Calcagno J, Kane M, Torgerson P, MartinezSilveira MS, et al. Global morbidity and mortality of leptospirosis: A systematic review. PLoS Negl Trop Dis. 2015;9(9):e0003898.

2. Rood EJJ, Goris MGA, Pijnacker R, Bakker MI, Hartskeerl RA. Environmental risk of leptospirosis infections in the Netherlands: Spatial modelling of environmental risk factors of leptospirosis in the Netherlands. PLoS One. 2017;12(10):e0186987.

3. Sumi A, Telan EF, Chagan-Yasutan H, Piolo MB, Hattori T, Kobayashi N. Effect of temperature, relative humidity and rainfall on dengue fever and leptospirosis infections in Manila, the Philippines. Epidemiol Infect. 2017;145(1):78-86.

4. Amilasan AS, Ujiie M, Suzuki M, Salva E, Belo MC, Koizumi N, et al. Outbreak of leptospirosis after flood, the Philippines, 2009. Emerg Infect Dis. 2012;18(1):91-4.

5. Lau CL, Smythe LD, Craig SB, Weinstein P. Climate change, flooding, urbanisation and leptospirosis: fuelling the fire? Trans $\mathrm{R}$ Soc Trop Med Hyg. 2010;104(10):631-8.

6. Haake DA, Dundoo M, Cader R, Kubak BM, Hartskeerl RA, Sejvar JJ, et al. Leptospirosis, water sports, and chemoprophylaxis. Clin Infect Dis. 2002;34(9):e40-e43.

7. Stern EJ, Galloway R, Shadomy SV, Wannemuehler K, Atrubin D, Blackmore C, et al. Outbreak of leptospirosis among Adventure Race participants in Florida, 2005. Clin Infect Dis. 2010;50(6):843-9.

8. Schneider MC, Jancloes M, Buss DF, Aldighieri S, Bertherat E, Najera P, et al. Leptospirosis: a silent epidemic disease. Int J Environ Res Public Health. 2013;10(12):7229-34.

9. Costa F, Martinez-Silveira MS, Hagan JE, Hartskeerl RA, Dos Reis MG, Ko AI. Surveillance for leptospirosis in the Americas, 19962005: a review of data from ministries of health. Rev Panam Salud Publica. 2012;32(3):169-77.

10. Olson DM, Dinerstein E, Wikramanayake ED, Burgess ND, Powell GVN, Underwood EC, et al. Terrestrial ecoregions of the world: a new map of life on earth: a new global map of terrestrial ecoregions provides an innovative tool for conserving biodiversity. BioScience. 2001;51:933-8.

11. Mohd Radi MF, Hashim JH, Jaafar MH, Hod R, Ahmad N, Mohammed Nawi A, et al. Leptospirosis outbreak after the 2014 major flooding event in Kelantan, Malaysia: a spatial-temporal analysis. Am J Trop Med Hyg. 2018;98(5):1281-95.

12. Dierks J, Servies T, Do T. A study on the leptospirosis outbreak among US marine trainees in Okinawa, Japan. Mil Med. 2018;183(3-4):e208-e212.

13. Togami E, Kama M, Goarant C, Craig SB, Lau C, Ritter JM, et al. A large leptospirosis outbreak following successive severe floods in Fiji, 2012. Am J Trop Med Hyg. 2018;99(4):849-51.

14. Guillois Y, Bourhy P, Ayral F, Pivette M, Decors A, Aranda Grau $\mathrm{JH}$, et al. An outbreak of leptospirosis among kayakers in Brittany, North-West France, 2016. Euro Surveill. 2018;23(48):1700848.

15. Dadon Y, Haas EJ, Kaliner E, Anis E, Singer SR, Atiya-Nasagi Y, et al. Outbreak of human leptospirosis linked to contaminated water bodies in Northern Israel, June to August 2018. Euro Surveill. 2018;23(38):1800486.

16. National Academies of Sciences, Engineering, and Medicine. Visions on potential priorities and actions for preparedness by 2030. In: Nicholson A, Shah CM, Ogawa VA, editors. Exploring lessons learned from a century of outbreaks: readiness for 2030. Proceedings of a workshop. Washington, DC: National Academies Press; 2019. p. 121-135.

17. Bandara K, Weerasekera MM, Gunasekara C, Ranasinghe N, Marasinghe C, Fernando N. Utility of modified Faine's criteria in diagnosis of leptospirosis. BMC Infect Dis. 2016;16(1):446.

18. Jiménez JIS, Marroquin JLH, Richards GA, Amin P. Leptospirosis: report from the task force on tropical diseases by the World Federation of Societies of Intensive and Critical Care Medicine. J Crit Care. 2018;43:361-5.

19. Sukmark T, Lumlertgul N, Peerapornratana S, Khositrangsikun K, Tungsanga K, Sitprija V, et al. Thai-Lepto-on-admission probability (THAI-LEPTO) score as an early tool for initial diagnosis of leptospirosis: result from Thai-Lepto AKI study group. PLoS Negl Trop Dis. 2018;12(3):e0006319.
20. Watson JT, Gayer M, Connolly MA. Epidemics after natural disasters. Emerg Infect Dis. 2007;13(1):1-5.

21. Haake DA, Levett PN. Leptospirosis in humans. Curr Top Microbiol Immunol. 2015;387:65-97.

22. World Health Organization. Managing epidemics: key facts about major deadly diseases. Geneva: WHO; 2018.

23. Picardeau M, Bertherat E, Jancloes M, Skouloudis AN, Durski K, Hartskeerl RA. Rapid tests for diagnosis of leptospirosis: current tools and emerging technologies. Diagn Microbiol Infect Dis. 2014;78(1):1-8.

24. Maze MJ, Cash-Goldwasser S, Rubach MP, Biggs HM, Galloway RL, Sharples KJ, et al. Risk factors for human acute leptospirosis in northern Tanzania. PLoS Negl Trop Dis. 2018;12(6):e0006372.

25. Crump JA, Morrissey AB, Nicholson WL, Massung RF, Stoddard RA, Galloway RL, et al. Etiology of severe non-malaria febrile illness in Northern Tanzania: a prospective cohort study. PLoS Negl Trop Dis. 2013;7(7):e2324.

26. Rubbo PA, Soupé-Gilbert ME, Golongba DM, Mbombo F, Girault D, Nakouné E, et al. Evidence of human leptospirosis cases in a cohort of febrile patients in Bangui, Central African Republic: a retrospective study, 2012-2015. BMC Infect Dis. 2018;18(1):376.

27. Zida S, Kania D, Sotto A, Brun M, Picardeau M, Castéra J, et al. Leptospirosis as cause of febrile icteric illness, Burkina Faso. Emerg Infect Dis. 2018;24(8):1569-72.

28. Bierque E, Thibeaux R, Girault D, Soupé-Gilbert ME, Goarant C. A systematic review of Leptospira in water and soil environments. PLoS One. 2020;15(1):e0227055.

29. Mason MR, Encina C, Sreevatsan S, Muñoz-Zanzi C. Distribution and diversity of pathogenic Leptospira species in peri-domestic surface waters from south central Chile. PLoS Negl Trop Dis. 2016;10(8):e0004895.

30. Muñoz-Zanzi C, Mason MR, Encina C, Astroza A, Romero A. Leptospira contamination in household and environmental water in rural communities in southern Chile. Int J Environ Res Public Health. 2014;11(7):6666-80.

31. Matsushita N, Ng CFS, Kim Y, Suzuki M, Saito N, Ariyoshi K, et al. The non-linear and lagged short-term relationship between rainfall and leptospirosis and the intermediate role of floods in the Philippines. PLoS Negl Trop Dis. 2018;12(4):e0006331.

32. Gutiérrez JD, Martínez-Vega RA. Spatiotemporal dynamics of human leptospirosis and its relationship with rainfall anomalies in Colombia. Trans R Soc Trop Med Hyg. 2018;112(3):115-23.

33. Casanovas-Massana A, Costa F, Riediger IN, Cunha M, de Oliveira D, Mota DC, et al. Spatial and temporal dynamics of pathogenic Leptospira in surface waters from the urban slum environment. Water Res. 2018;130:176-84.

34. Casanovas-Massana A, Pedra GG, Wunder EA Jr, Diggle PJ, Begon M, Ko AI. Quantification of Leptospira interrogans survival in soil and water microcosms. Appl Environ Microbiol. 2018;84(13):e00507-e00518.

35. Riediger IN, Hoffmaster AR, Casanovas-Massana A, Biondo AW, Ko AI, Stoddard RA. An optimized method for quantification of pathogenic Leptospira in environmental water samples. PLoS One. 2016;11(8):e0160523.

36. Galloway R, Stoddard RA, Schafer IJ. Infectious diseases related to travel: Leptospirosis. In: Centers for Disease Control and Prevention. CDC yellow book 2018: health information for international travel. New York: Oxford University Press; 2017.

37. Schneider MC, Velasco-Hernandez J, Min KD, Leonel DG, BacaCarrasco D, Gompper ME, et al. The use of chemoprophylaxis after floods to reduce the occurrence and impact of leptospirosis outbreaks. Int J Environ Res Public Health. 2017;14(6):594.

38. Spichler A, Athanazio DA, Vilaça P, Seguro A, Vinetz J, Leake JA. Comparative analysis of severe pediatric and adult leptospirosis in Sao Paulo, Brazil. Am J Trop Med Hyg. 2012;86(2):306-8.

39. Rajajee S, Shankar J, Dhattatri L. Pediatric presentations of leptospirosis. Indian J Pediatr. 2002;69(10):851-3.

40. Daher EF, Vieira AP, Jacinto CN, Lima RS, Girão MM, Fernandes AT, et al. Differences among children, adolescents and adults with 
severe leptospirosis: a comparative analysis. Indian J Nephrol. 2014;24(3):166-70.

41. Tomari K, Toyokawa T, Takahashi T, Kakita T, Okano S, Kyan $\mathrm{H}$, et al. Childhood leptospirosis in an industrialized country: population-based study in Okinawa, Japan. PLoS Negl Trop Dis. 2018;12(3):e0006294.

42. Tullu MS, Karande S. Leptospirosis in children: a review for family physicians. Indian J Med Sci. 2009;63(8):368-78.

43. Pereira MM, Schneider MC, Munoz-Zanzi C, Costa F, Benschop J, Hartskeerl R, et al. A road map for leptospirosis research and health policies based on country needs in Latin America. Rev Panam Salud Publica. 2018;41:e131.

Manuscript received on 25 September 2019. Revised version accepted for publication on 17 April 2020.

\section{Revisión sistemática de los brotes de leptospirosis en el mundo, 1970-2012}

RESUMEN Objetivo. Describir la distribución geográfica y temporal, los métodos de detección y otras características epidemiológicas de los brotes de leptospirosis publicados con el fin de fundamentar los esfuerzos tendientes a estandarizar las prácticas empleadas en la notificación de brotes.

Métodos. Se llevó a cabo una revisión sistemática de los brotes de leptospirosis notificados en la bibliografía científica y en ProMED entre 1970 y 2012. Se utilizaron criterios predefinidos para identificar y clasificar los brotes y se empleó un formulario estándar para extraer la información.

Resultados. Entre 1970 y 2012 se identificaron 318 brotes (promedio: 7 brotes/año; rango: 1-19), la mayoría de ellos en América Latina y el Caribe (36\%), región seguida por Asia meridional (13\%) y América del Norte (11\%). La mayoría de los brotes se localizaron en ecorregiones tropicales y subtropicales (55\%). La clasificación cualitativa reveló que en el 40\% de los brotes había una clara descripción de los casos confirmados por laboratorio. Entre ellos, el tamaño promedio del brote fue de 82 casos (rango: 2-2259 casos) pero alcanzó los 253 casos en ecorregiones tropicales o subtropicales. Entre los factores de riesgo frecuentes figuraban las actividades laborales al aire libre (25\%), la exposición a agua proveniente de inundaciones (23\%) y la exposición a agua con fines recreativos (22\%). En el $80 \%$ de los brotes se realizaron investigaciones epidemiológicas, principalmente entrevistas de casos. La mortalidad específica de los casos fue del 5\% (rango: 0\%-60\%).

Conclusiones. La notificación de brotes aumentó durante el período de estudio, y los brotes abarcaron regiones tropicales y no tropicales. Los brotes fueron diferentes en cuanto a su tamaño, el entorno y los factores de riesgo; sin embargo, los datos examinados con frecuencia incluían una información limitada respecto del diagnóstico y la epidemiología. Se recomiendan directrices para elaborar procedimientos estandarizados para las investigaciones diagnósticas y epidemiológicas durante un brote y para su notificación.

Palabras clave Leptospirosis; Leptospira; brotes de enfermedades; zoonosis; vigilancia en salud pública. 